Satoru Nishikawa*, Tadayuki Hasegawa and Makoto Takahashi

\title{
Effect of PWHT Conditions on Toughness and Creep Rupture Strength in Modified 9Cr-1Mo Steel Welds
}

https://doi.org/10.1515/htmp-2019-0031

Received November 01, 2018; accepted December 12, 2018

\begin{abstract}
We clarified the effect of post weld heat treatment (PWHT) conditions on the toughness and creep rupture strength of modified $9 \mathrm{Cr}$-1Mo steel weldments used for high temperature components of ultra-supercritical power plants. Fracture appearance transition temperature (FATT) decreased as PWHT temperature increased, and for all of the weld metals of tungsten inert gas welding, submerged arc welding and shielded metal arc welding, FATTs were lower than $293 \mathrm{~K}$ when the PWHT temperature was higher than $1,008 \mathrm{~K}$. In contrast, in the uniaxial creep test with a loaded stress of $108 \mathrm{MPa}$, the creep rupture strength of the specimen on which PWHT was carried out for a holding time of $7.2 \mathrm{ks}$ was significantly decreased when the PWHT temperature was more than $1,033 \mathrm{~K}$. Therefore, the appropriate PWHT temperature range to maintain the toughness and creep fracture strength was $1,008 \mathrm{~K} \leq T \leq 1,033 \mathrm{~K}$.
\end{abstract}

Keywords: modified 9Cr-1Mo steel welds; fine grain HAZ; creep rupture strength; PWHT; VN; chromium carbide

\section{Introduction}

Steam conditions in thermal power plants are high-temperature high-pressure to decrease the emission of $\mathrm{CO}_{2}$, ultra-supercritical (USC) plant with main steam temperature at $600^{\circ} \mathrm{C}$ is operating. The main steam piping and the overheated steam piping of USC plants cannot use $1.25 \mathrm{Cr}-0.5 \mathrm{Mo}$ steel or $2.25 \mathrm{Cr}-1$ Mo steel, which are widely used in conventional thermal power plants, because their creep strength is insufficient. Therefore, modified $9 \mathrm{Cr}-$ 1Mo steel (Ka STPA28, Grade 91) is used for the piping in USC plants as its high creep strength is strengthened

*Corresponding author: Satoru Nishikawa, Department of Physical Science and Materials Engineering, Iwate University, Morioka, Japan, E-mail: satorun@iwate-u.ac.jp

Tadayuki Hasegawa, Japan Power Engineering and Inspection Corporation, Tokyo, Japan, E-mail: Hasegawa-tadayuki@japeic.or.jp Makoto Takahashi, Joining and Welding Research Institute, Osaka University, Osaka, Japan, E-mail: makotot@jwri.osaka-u.ac.jp by fine precipitation of $\mathrm{Nb}$ and $\mathrm{V}$ carbonitrides. The modified 9Cr-1Mo steel is a higher creep strength compared with $1.25 \mathrm{Cr}-0.5 \mathrm{Mo}$ steel and $2.25 \mathrm{Cr}-1 \mathrm{Mo}$ steel. However, it is known that creep damage (Type IV flaw) occurs in the fine grain heat-affected zone (FGHAZ) of the welded joints [1-3].

Post weld heat treatment (PWHT) has to be applied to the modified $9 \mathrm{Cr}-1 \mathrm{Mo}$ steel for the purpose to decrease residual stress and improve the toughness of the welds, which has low toughness in the as-welded state [4]. It is known that the toughness of the weld metal of the $9 \mathrm{Cr}$ steel changes depending on oxygen content [5]. Weld metal with a high oxygen content such as shielded metal arc welding (SMAW) and submerged arc welding (SAW) has low toughness in its as-welded state; therefore, it is important to apply PWHT to improve the toughness of the weld metal. However, it is necessary to find the PWHT temperature range for satisfying both creep rupture strength and toughness of the weld metal, as there is little published data on the relationship between the PWHT temperature and the creep rupture strength of the modified $9 \mathrm{Cr}-1$ Mo steel welds.

In this research, we investigated the necessary PWHT temperature for improving the toughness of the weld metal in each welding process. Furthermore, we investigated the relationship between PWHT conditions (temperature, holding time) and creep rupture strength for the modified 9Cr-1Mo steel (Ka STPA28) welded joints and found the optimum PWHT conditions for satisfying both the toughness of the weld metal and the creep rupture strength of the welded joint.

\section{Experimental}

\section{Materials and welding procedure}

Welded joints for toughness evaluation of weld metals

Figure 1 shows the edge shape of welded joints for toughness evaluation of weld metals. Welded joints were made 


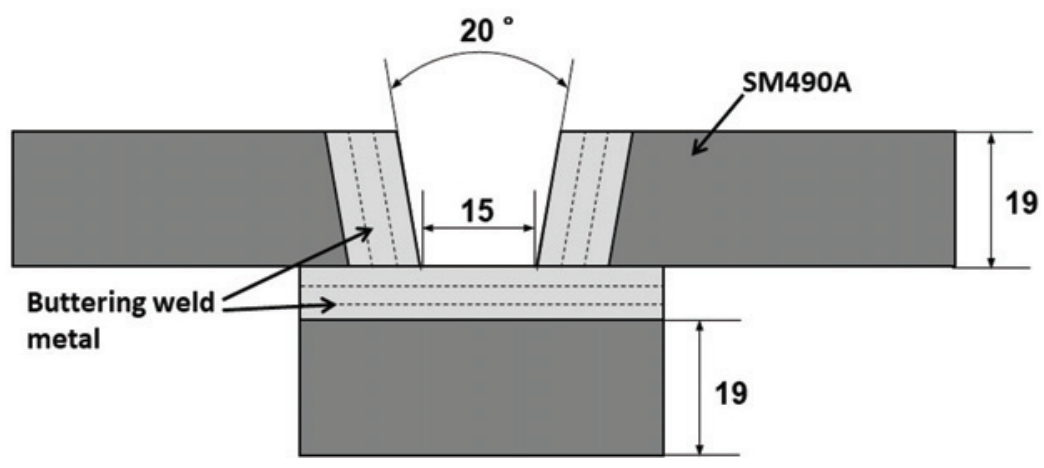

Figure 1: Edge shape of welded joints for evaluation of toughness.

using SMAW, SAW and tungsten inert gas welding (TIG welding). The groove faces of the SMAW and SAW joints were buttered with three layers of SMAW metal, and the TIG welding joints were buttered with three layers of TIG weld metal. Table 1 shows welding conditions and Table 2 shows the chemical composition of each of the weld metals. PWHT was applied to the welded joints for $7.2 \mathrm{ks}$ at $953-1,073 \mathrm{~K}$. In addition, the heating rate during PWHT was $0.028 \mathrm{~K} / \mathrm{s}$ and the cooling rate was $0.036 \mathrm{~K} / \mathrm{s}$.

\section{Welded joints for evaluation of creep rupture strength}

Figure 2 shows the edge shape of the butt circumferential welded joint comprising Ka STPA28 piping with a thickness of $32.0 \mathrm{~mm}$, outside diameter of $317.0 \mathrm{~mm}$ and a length of $190 \mathrm{~mm}$. The groove preparation was centered in the length of the piping. Further, the welding process was TIG welding in the flat welding position around the entire circumference. The welding condition comprised a current of $190 \mathrm{~A}$, voltage of $14 \mathrm{~V}$, welding speed of $1.67 \mathrm{~mm} / \mathrm{s}$, wire feeding speed of $0.17 \mathrm{~g} / \mathrm{s}$ and a preheating and interpass temperature of $513-623 \mathrm{~K}$. Table 3 shows the chemical composition of the filler wire and base metal.

\section{The Charpy impact test}

The Charpy impact test specimens, each with a 2-mmdeep V-notch, were taken transverse to the welding direction from the center of the plate thickness of the welded joints described in the "Welded joints for toughness evaluation of weld metals" section. A V-notch was added to the center of the weld metal. The Charpy impact test was carried out at $183-513 \mathrm{~K}$, and the fracture appearance

Table 1: Welding condition of SMAW, SAW and TIG welded joint.

\begin{tabular}{lrrrrrrr}
\hline Welded joint & Polarity & $\begin{array}{r}\text { Current } \\
(\mathbf{A})\end{array}$ & $\begin{array}{r}\text { Voltage } \\
(\mathbf{V})\end{array}$ & $\begin{array}{r}\text { Welding speed } \\
(\mathbf{m m} / \mathbf{s})\end{array}$ & $\begin{array}{r}\text { Wire feeding speed } \\
(\mathbf{g} / \mathbf{s})\end{array}$ & $\begin{array}{r}\text { Pass } \\
\text { number }\end{array}$ & $\begin{array}{r}\text { Preheat and interpass } \\
\text { temperature (K) }\end{array}$ \\
\hline SMAW & AC & 150 & 26 & $1.73-2.28$ & - & 12 & \\
SAW & AC & 500 & 31 & 6.67 & - & 13 & $523-623$ \\
TIG welding & DCEN & 230 & 11 & 1.33 & 0.24 & 18 & \\
\hline
\end{tabular}

Table 2: Chemical composition of weld metal (mass\%).

\begin{tabular}{|c|c|c|c|c|c|c|c|c|c|c|c|c|}
\hline Welding process & C & $\mathbf{S i}$ & $M n$ & $\mathbf{P}$ & $\mathbf{S}$ & $\mathbf{N i}$ & $\mathrm{Cr}$ & Mo & $\mathbf{v}$ & Nb & $O(p p m)$ & $\mathrm{N}(\mathrm{ppm})$ \\
\hline SMAW & 0.083 & 0.41 & 1.63 & 0.006 & 0.002 & 0.97 & 8.68 & 1.05 & 0.22 & 0.028 & 360 & 280 \\
\hline SAW & 0.076 & 0.17 & 1.76 & 0.006 & 0.004 & 0.64 & 8.13 & 0.90 & 0.22 & 0.034 & 420 & 280 \\
\hline TIG welding & 0.091 & 0.15 & 0.96 & 0.005 & 0.002 & 0.66 & 8.84 & 0.87 & 0.17 & 0.030 & 12 & 170 \\
\hline
\end{tabular}




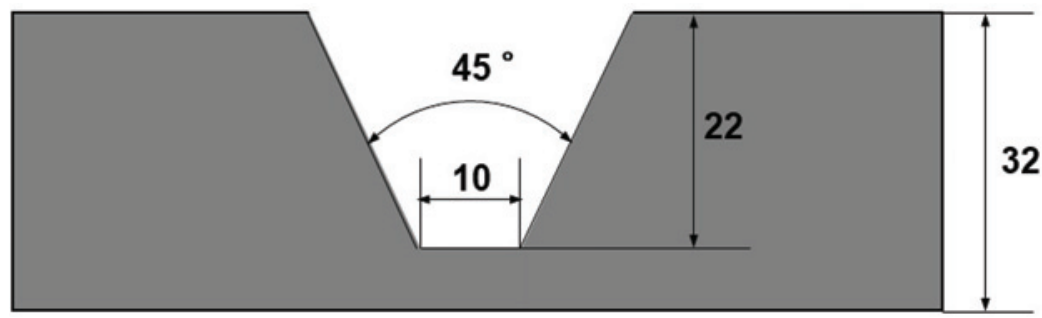

Figure 2: Edge shape of welded joint for creep rupture strength evaluation.

Table 3: Chemical composition of filler wire and base metal (mass\%).

\begin{tabular}{|c|c|c|c|c|c|c|c|c|c|c|c|}
\hline Material & C & Si & $M n$ & $\mathbf{P}$ & S & $\mathrm{Ni}$ & $\mathrm{Cr}$ & Mo & v & $\mathrm{Nb}$ & $\mathrm{N}(\mathrm{ppm})$ \\
\hline Filler wire & 0.07 & 0.15 & 0.99 & 0.006 & 0.004 & 0.67 & 8.97 & 0.88 & 0.17 & 0.04 & 200 \\
\hline Ka STPA28 & 0.11 & 0.24 & 0.46 & 0.008 & 0.001 & 0.15 & 8.81 & 0.97 & 0.19 & 0.07 & 410 \\
\hline
\end{tabular}

transition temperature (FATT) was obtained by measuring the brittle surface ratio and amount of lateral expansion at each test temperature.

\section{Creep test}

Round bar specimens of $\varphi 18$ and $80 \mathrm{~mm}$ length were taken from the axial direction at $11 \mathrm{~mm}$ depth from the surface of the center of the weld. Specimens were heat treated for $0-115.2 \mathrm{ks}$ at $953-1,073 \mathrm{~K}$. In addition, the heating and cooling rates during heat treatment were the same as in the "Welded joints for toughness evaluation of weld metals" section. A schematic diagram of creep specimens is shown in Figure 3. A creep test specimen was machined on a round bar specimen, and the creep test was carried out at a single load stress of $108 \mathrm{MPa}$ at $893 \mathrm{~K}$ to determine the creep rupture time.

\section{Metallurgical investigation}

Optical observations and field emission scanning electron microscopy (FE-SEM) observations after 5\% nitric acid ethanol etching were carried out. Further, FE transmission electron microscopy (TEM) observation using X-ray energy dispersive spectrometry (EDS) by thin-film specimens was carried out. The acceleration voltage of FE-SEM observation was $5 \mathrm{kV}$. The thin-film specimens used for TEM observation were fabricated using a focused ion beam processing apparatus, and the acceleration of FETEM observation and EDS analysis was $200 \mathrm{kV}$. The beam

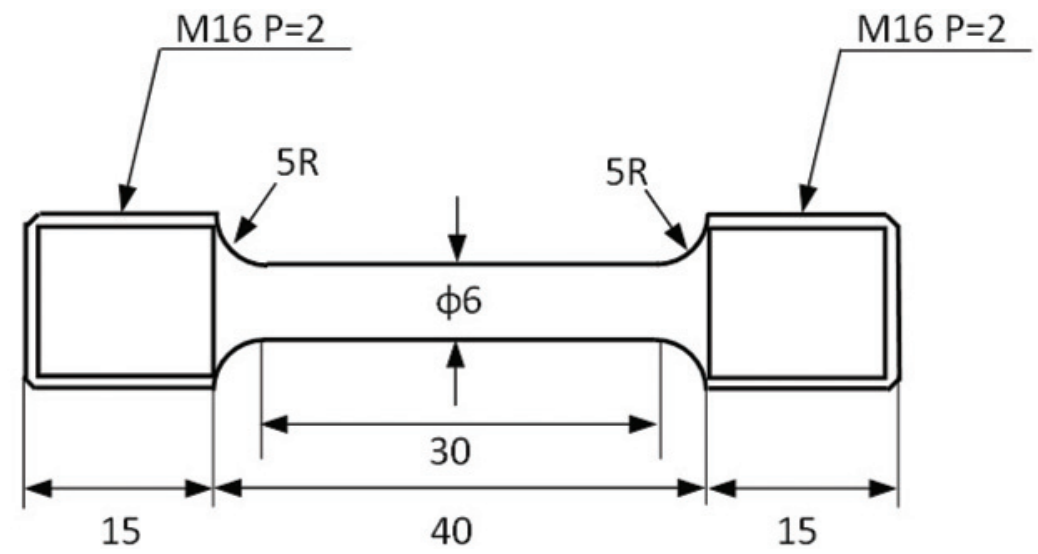

Figure 3: Schematic diagram of creep specimen. 
diameter during EDS analysis was about $\varphi 1 \mathrm{~nm}$. In addition, the hardness distribution of the welds was measured by the Vickers hardness measurement at $9.8 \mathrm{~N}$.

\section{Results and discussion}

\section{Effect of PWHT temperature on the toughness of weld metals}

Figures 4 and 5 show the changes in the brittle fracture rate and the amount of lateral expansion on the Charpy impact test temperature of each weld metal in the welded state, respectively. The FATT of the SMAW, the SAW and TIG weld metals are $423 \mathrm{~K}, 403 \mathrm{~K}$ and $303 \mathrm{~K}$, respectively. The TIG weld metal has higher toughness because the FATT is lower. The amount of lateral expansion of the SMAW metal and the SAW metal is less than $0.5 \mathrm{~mm}$ when the brittle fracture rate is $0 \%$. However, as the amount of lateral expansion of the TIG weld metal is $1.6 \mathrm{~mm}$, the toughness of the TIG weld metal at $100 \%$ ductile fracture is higher than the SMAW and the SAW metals. The high toughness of the TIG weld metal is considered to be one of the reasons why the oxygen content is lower than that of the SMAW and the SAW metals. The toughness of $9 \mathrm{Cr}$ steel weld metals is consistent with the result that there is a correlation with oxygen content. Figures 6 and 7 show the changes in the brittle fracture rate and amount of lateral expansion on the Charpy impact test temperature of the SMAW metals subjected to the PWHT, respectively. When the PWHT temperature is $953 \mathrm{~K}$, the FATT decreased to $363 \mathrm{~K}$. The FATT of the PWHT temperature at $1,033 \mathrm{~K}$ further decreased to $273 \mathrm{~K}$. The amount of lateral expansion at $100 \%$ ductile fracture increased with the increase in PWHT temperature, which suggests that the PWHT improved the toughness of the weld metal. Figure 8 shows the relationship between the PWHT temperature and FATT of the weld metals and the base metal. The FATT related to the toughness of the weld metals decreased with increasing PWHT temperature. Usually, it is the pressure test that the toughness of the welded joint is required, if the toughness of the welded joint is low during the pressure test, brittle fracture may occur. As the lowest pressure test temperature specified by ASME Sec. I is $293 \mathrm{~K}$, the PWHT temperature at which the FATT decreases below $293 \mathrm{~K}$ was found above $1,008 \mathrm{~K}$ in the SMAW metal as shown in Figure 8. Therefore, it is considered that sufficient toughness can be obtained if the PWHT temperature is above $1,008 \mathrm{~K}$. However, when the PWHT temperature of the SMAW metal reached $1,073 \mathrm{~K}$, the FATT increased. This was probably precipitated on the fresh martensite in the weld metal beyond the $\mathrm{Ac}_{1}$ transformation temperature.

\section{Effect of PWHT temperature on the creep rupture strength in welds}

Figure 9 shows the relationship between the PWHT temperature and creep rupture time when the PWHT holding

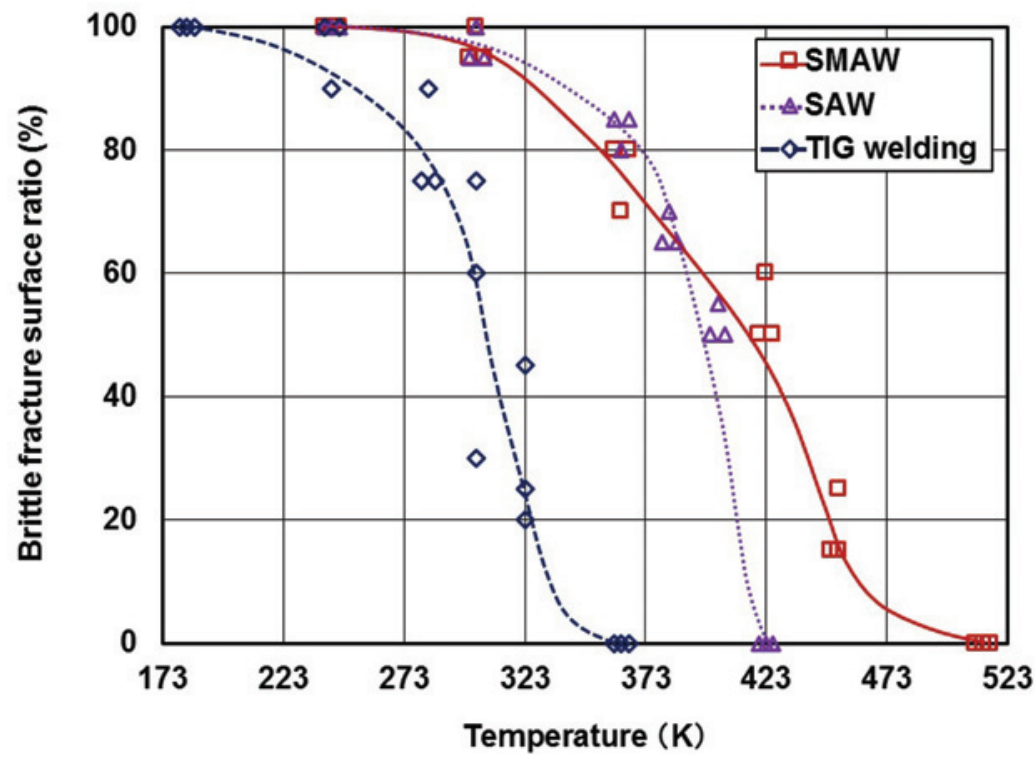

Figure 4: Effect of welding process on brittle fracture surface ratio of weld metals of the as-welded state. 

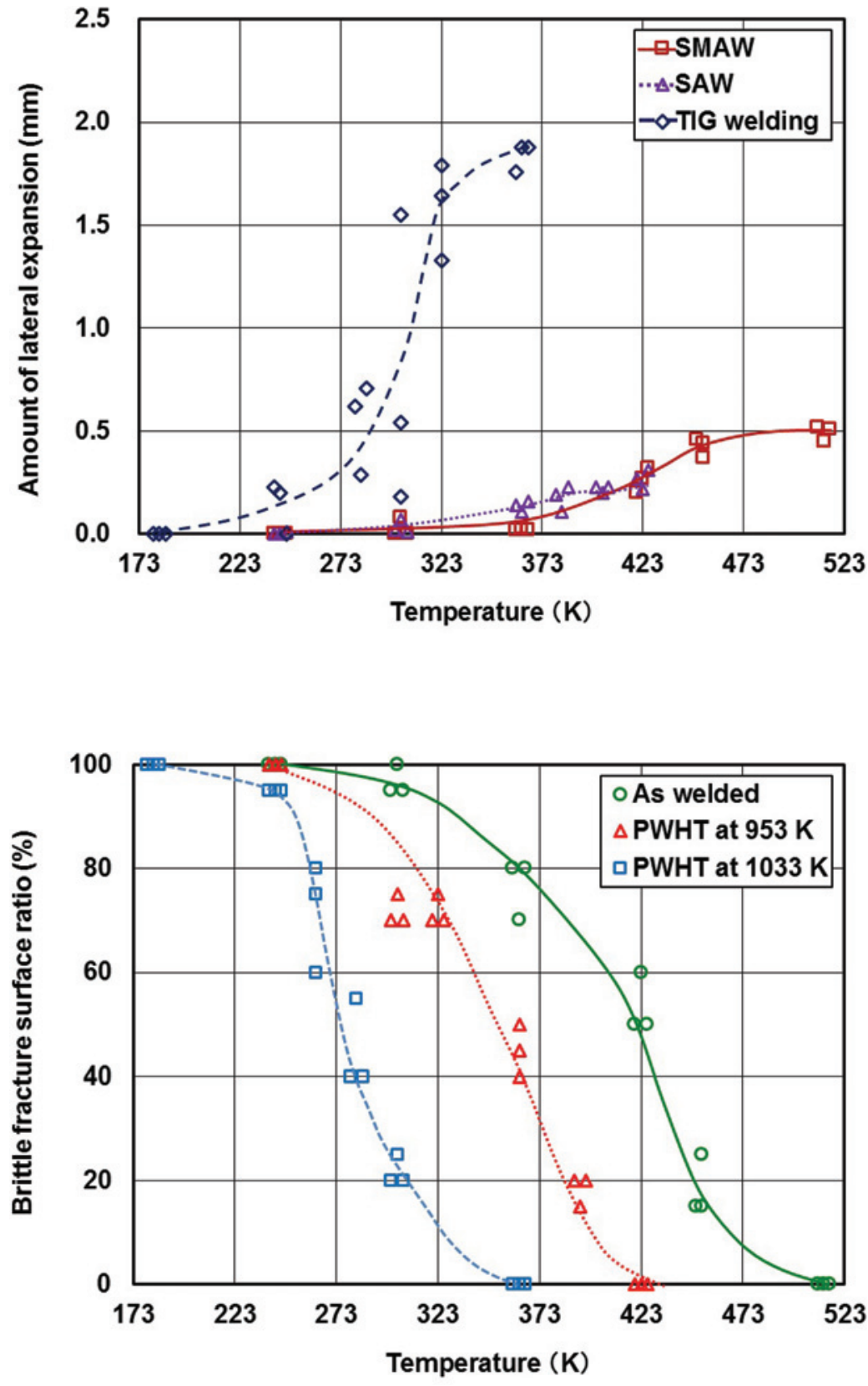

Figure 5: Effect of welding process on amount of lateral expansion of weld metals of the as-welded state.
Figure 6: Effect of PWHT temperature on brittle fracture surface ratio of SMAW metals. time is for $7.2 \mathrm{ks}$. The creep rupture time was nearly the same when the PWHT temperature was under 1,033 K. However, the creep rupture time above $1,033 \mathrm{~K}$ was shorter than that under $1,033 \mathrm{~K}$; the creep rupture time when the PWHT temperature was $1,073 \mathrm{~K}$ was about $1 / 7$ of that at $1,033 \mathrm{~K}$. Therefore, it is desirable to set the PWHT temperature under $1,033 \mathrm{~K}$ to achieve satisfactory creep strength of the welded joint. It should be noted that the load stress of the creep test is $108 \mathrm{MPa}$, which is much higher than the load stress experienced during USC plant operation. In the future, it is important to clarify whether the same PWHT temperature range will be obtained with low load stress. Therefore, as it is necessary to set the PWHT temperature above $1,008 \mathrm{~K}$ to satisfy the toughness of the weld metal, the PWHT temperature $(T)$ range necessary to satisfy both the creep rupture strength and the toughness is considered to be $1,008 \mathrm{~K} \leqq T \leqq 1,033 \mathrm{~K}$.

Figure 10 shows macrographs of cross sections of creep rupture areas at PWHT temperatures of 1,033 and $1,073 \mathrm{~K}$. When the PWHT temperature was $1,033 \mathrm{~K}$, the FGHAZ 2-3 mm from the fusion line ruptured. However, when the PWHT temperature was $1,073 \mathrm{~K}$, the weld metal 

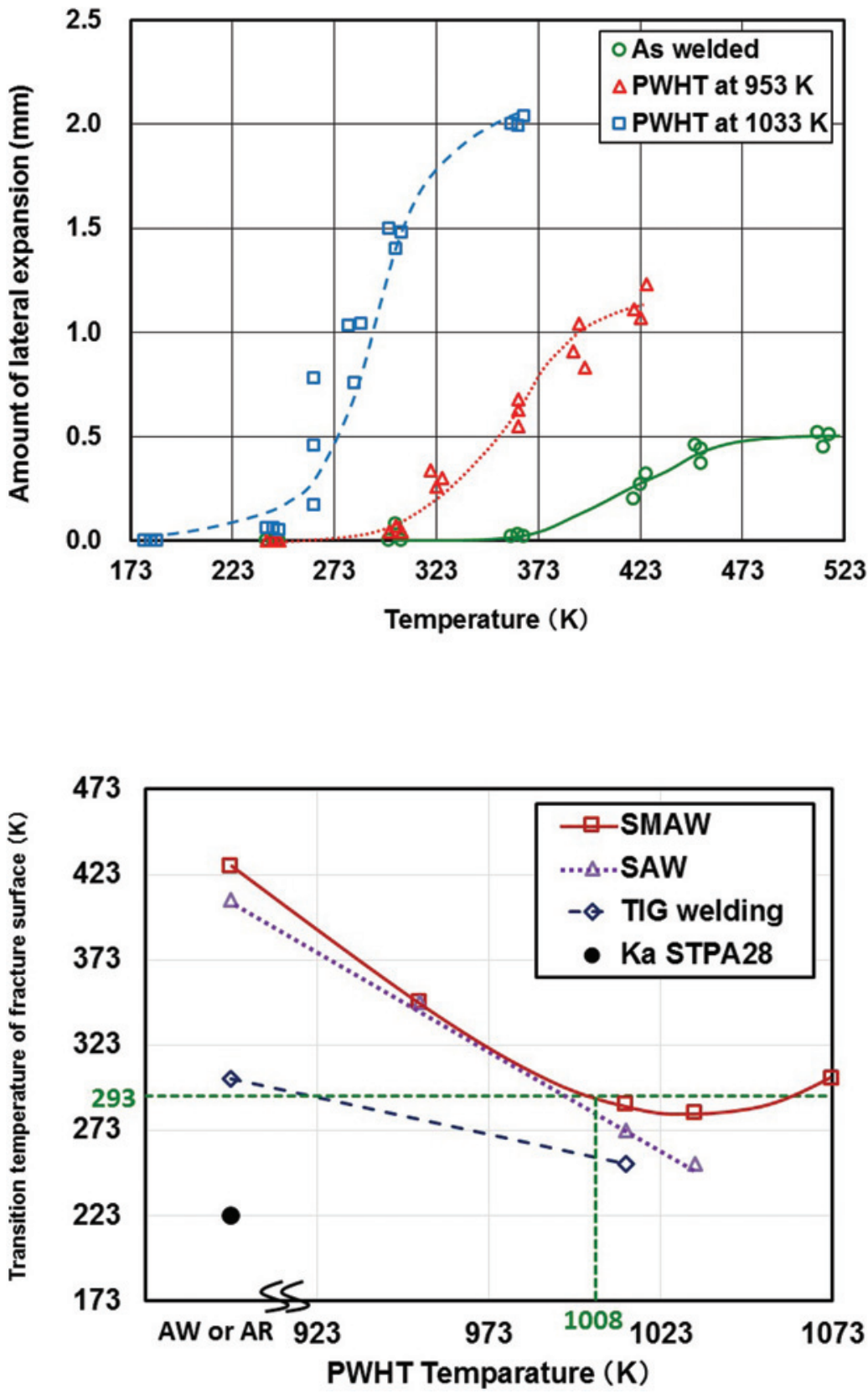

Figure 7: Effect of PWHT temperature on amount of lateral expansion of SMAW metals.
Figure 8: Transition temperature of fracture surface of weld metals subjected to the PWHT. ruptured, and many cracks and voids were observed in the neighboring rupture area. One of the reasons why the specimen subjected to PWHT at $1,073 \mathrm{~K}$ ruptured is that the weld metal is considered to have exceeded the $\mathrm{Ac}_{1}$ temperature during PWHT. In the previous research $[2,3]$, it has been shown that the creep rupture strength decreases when the $\mathrm{Ac}_{1}$ temperature exceeds during welding. The $\mathrm{Ac}_{1}$ temperature decreases as the $\mathrm{Ni}+\mathrm{Mn}$ content increases, and as the $\mathrm{Ni}+\mathrm{Mn}$ content of the weld metal is about 2.7 times that of the base metal, the weld metal has a lower $\mathrm{Ac}_{1}$ temperature than the base metal.
Based on the relationship between the $\mathrm{Ni}+\mathrm{Mn}$ content and the $\mathrm{Ac}_{1}$ temperature in the EPRI technical report [6], the $\mathrm{Ac}_{1}$ temperature of the weld metal can be estimated to be $1,043 \mathrm{~K}$. Therefore, it is considered that the rupture of the weld metal subjected to PWHT at $1,073 \mathrm{~K}$ is transformed in austenite above the $\mathrm{Ac}_{1}$ temperature during the PWHT. Figure 11 shows the hardness distribution of the welds. The hardness of the weld decreased as the PWHT temperature increased, and the hardness of FGHAZ at $2-3 \mathrm{~mm}$ from the fusion line was the lowest. This result is consistent with results from the previous 


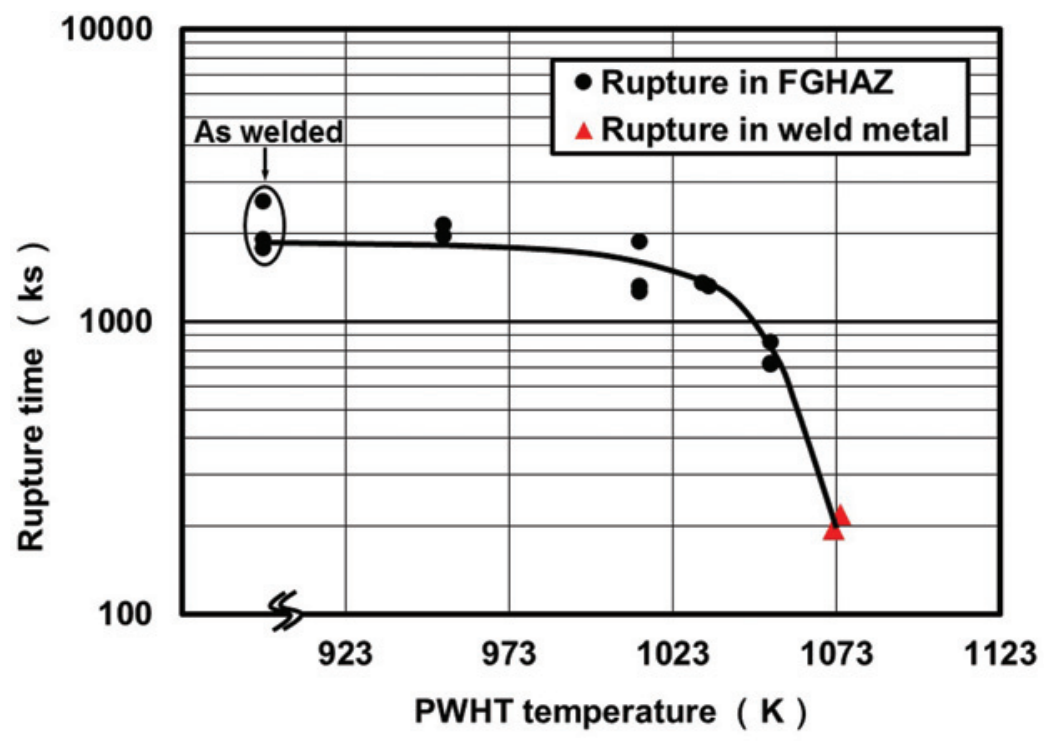

Figure 9: Effect of PWHT temperature on creep rupture time of welded joints.

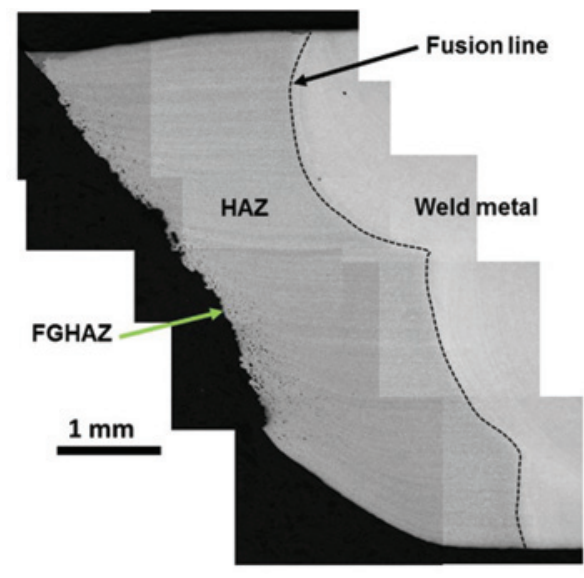

(a)

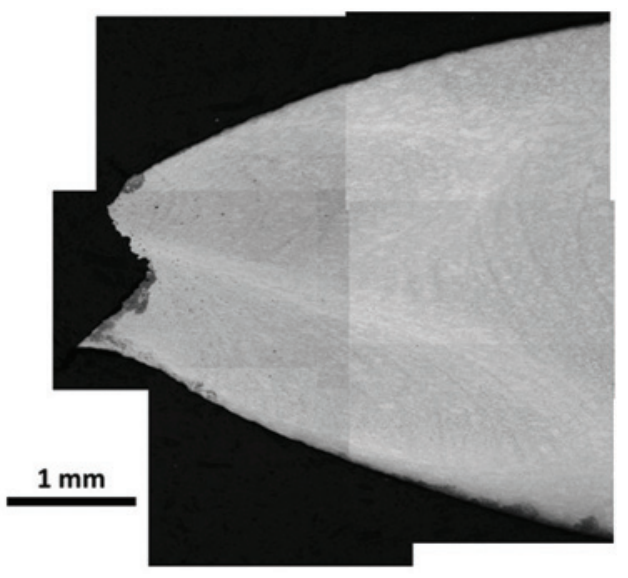

(b)

Figure 10: Optical micrographs of creep rupture region of specimens subjected to the PWHT: (a) 1,033 K and (b) 1,073 K.

research [7-10] where hardness of the FGHAZ was the lowest. The hardness of weld metal and FGHAZ subjected to PWHT at $1,073 \mathrm{~K}$, which ruptured in the weld metal, was almost the same value. Figure 12 shows SEM micrographs near the fracture surface at PWHT temperatures of 953-1,073 K. Microcracks were observed at the primary austenite grain boundaries of both FGHAZ and weld metal, and it was suggested that the primary austenite grain boundary was the starting point of creep rupture.

As the creep rupture strength decreased when the PWHT temperature was above $1,033 \mathrm{~K}$, the reason was clarified by observing the microstructure. Figure 13 shows optical micrographs of FGHAZ and weld metal before the creep test at each PWHT temperature. The microstructure of FGHAZ was almost the same at each PWHT temperature; however, the martensite lath of the weld metal was shown to coarsen at 1,073 K. Figure 14 shows TEM micrographs and EDS results of $\mathrm{Cr}$ and $\mathrm{V}$ after the creep tests. The bright area in the content distribution of $\mathrm{Cr}$ and $\mathrm{V}$ indicates that the content is high. The grain size of the FGHAZ was $1-4 \mu \mathrm{m}$, which was almost the same at each PWHT temperature. According to our previous study [7], it is considered that the regions where $\mathrm{Cr}$ and $\mathrm{V}$ are enriched are $\mathrm{M}_{23} \mathrm{C}_{6}$ and $\mathrm{VN}$. The maximum size of $\mathrm{M}_{23} \mathrm{C}_{6}$ at a PWHT temperature of $1,033 \mathrm{~K}$ was $0.3 \mu \mathrm{m}$; however, it was $0.5 \mu \mathrm{m}$ at 1,053 and $1,073 \mathrm{~K}$. As the PWHT 


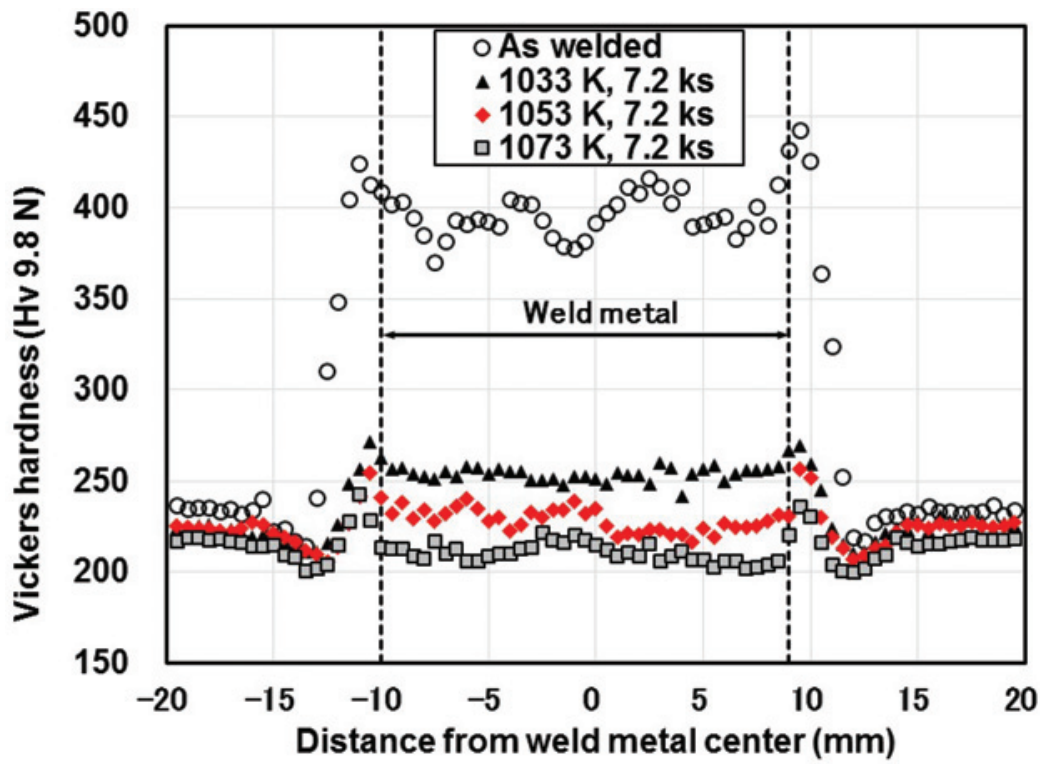

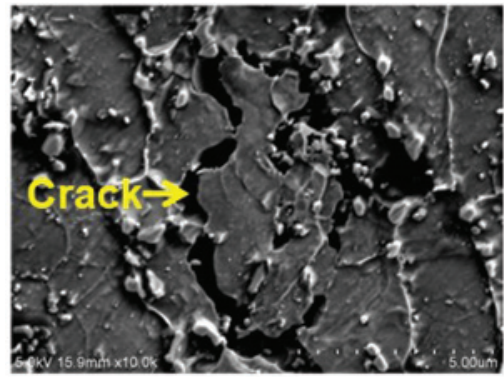

(a)

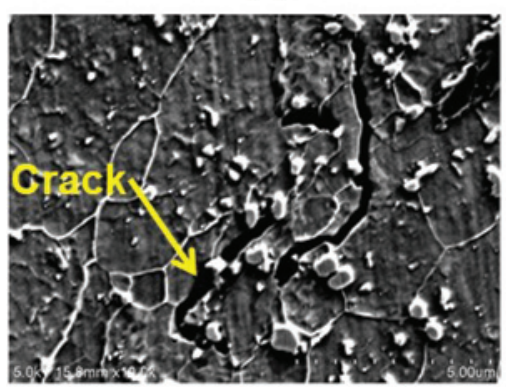

(c)

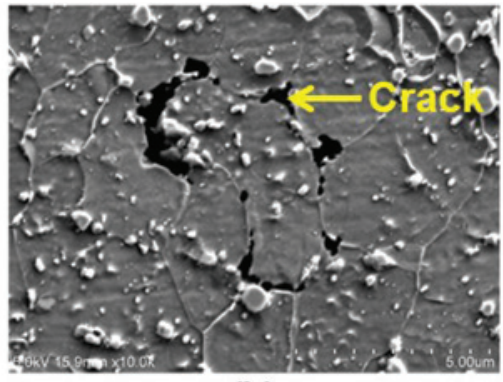

(b)

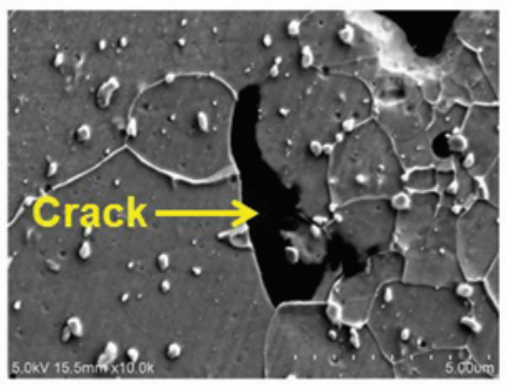

(d)
$5 \mu \mathrm{m}$
Figure 11: Comparison of Vickers hardness distributions in the welds at different PWHT temperature (before creep test).
Figure 12: SEM micrographs near creep rupture region of specimens subjected to the PWHT:

(a) $953 \mathrm{~K}$, (b) $1,033 \mathrm{~K}$, (c) $1,053 \mathrm{~K}$ and (d) $1,073 \mathrm{~K}$. temperature increased, $\mathrm{M}_{23} \mathrm{C}_{6}$ in FGHAZ coarsened. As it is almost the same in the number of $\mathrm{M}_{23} \mathrm{C}_{6}$ in the observation field, it is considered that the $\mathrm{Cr}$ content in the matrix phase is decreased due to the coarsening of $\mathrm{M}_{23} \mathrm{C}_{6}$. Further, $\mathrm{M}_{23} \mathrm{C}_{6}$ in the weld metal with PWHT temperature $1,073 \mathrm{~K}$ creep ruptured in weld metal has a maximum dimension of $1 \mu \mathrm{m}$, which is coarser than the dimension of $\mathrm{M}_{23} \mathrm{C}_{6}$ in FGHAZ. Similarly, for $\mathrm{VN}$, dimension of the
PWHT temperature $1,033 \mathrm{~K}$ was less than $0.1 \mu \mathrm{m}$; however, it grew to $0.2 \mu \mathrm{m}$ at 1,053 and $1,073 \mathrm{~K}$. Therefore, the grain dimension of the FGHAZ is almost the same at each PWHT temperature; however, $\mathrm{M}_{23} \mathrm{C}_{6}$ and VN coarsened when the PWHT temperature reached above $1,033 \mathrm{~K}$. As a result, for the solid solution strengthening and the precipitation strengthening of the matrix phase decreased, it is considered that large creep deformation 


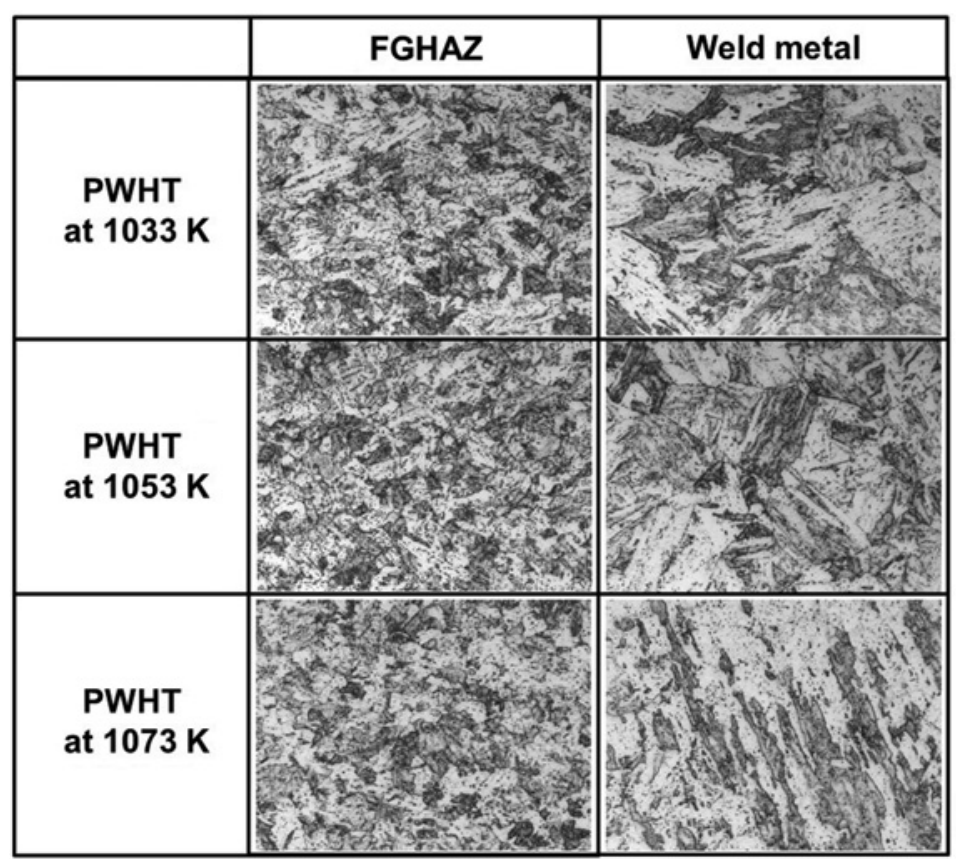

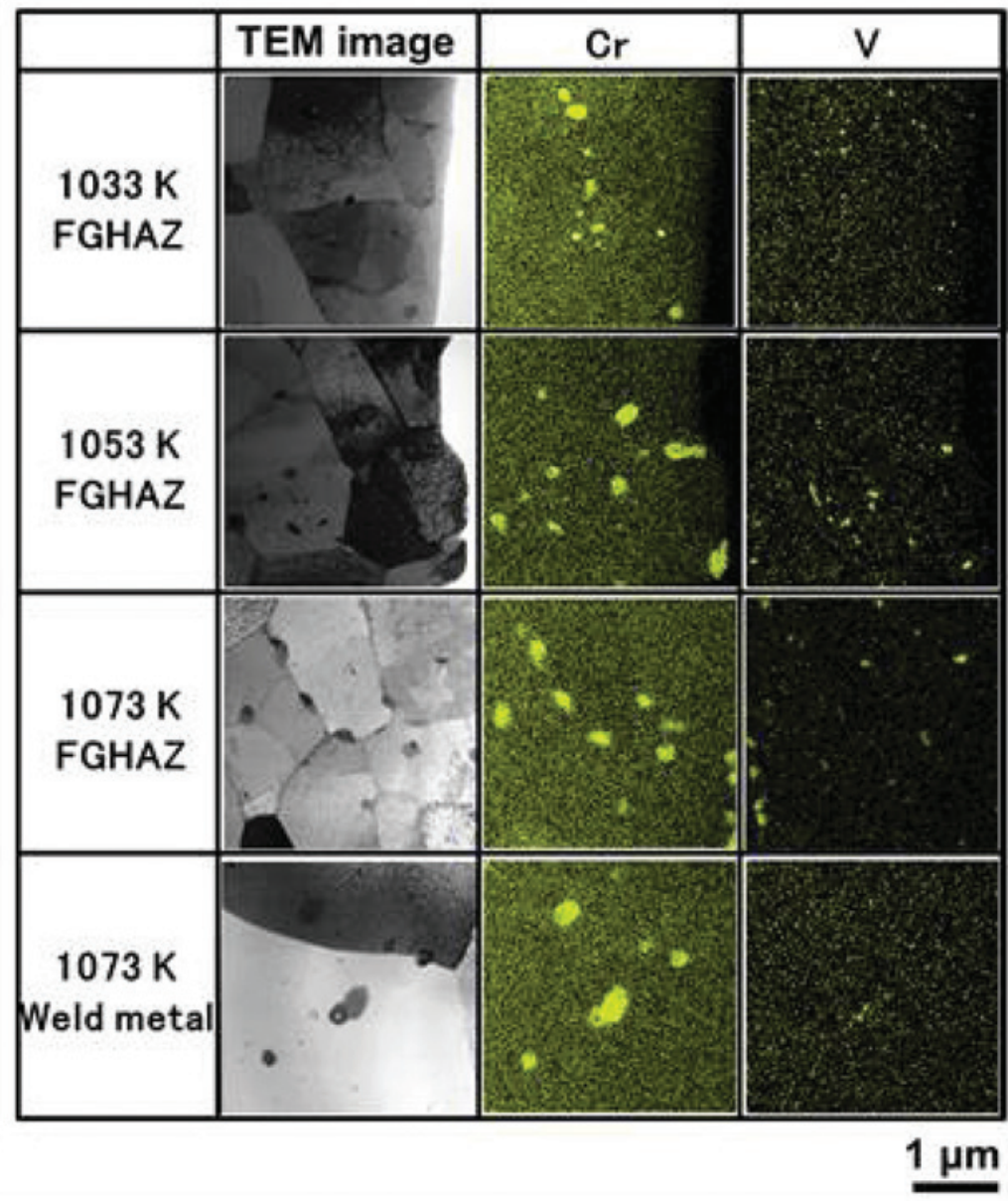

Figure 13: Optical micrographs of FGHAZ and weld metals subjected to the PWHT at 1,033-1,073 K before creep test.
Figure 14: TEM micrographs and $\mathrm{Cr}, \mathrm{V}$ distribution in FGHAZ and weld metals after creep test. 
occurs due to the movement easily of dislocations during loading stress. Then, primary austenite grain boundaries at which impurity elements tend to be concentrated cannot tolerate large creep deformation, and cracks and voids occur. As a result, it is inferred that creep rupture occurred in a short time.

\section{Effect of PWHT holding time at 1,033 K on the creep rupture strength in welds}

Figure 15 shows the relationship between the holding time of PWHT and creep rupture time at a PWHT temperature of $1,033 \mathrm{~K}$. The time until creep rupture decreases as the holding time of PWHT increases, and the creep rupture strength reduces. In the relevant regulations and codes, it is detailed that the holding time of PWHT generally increases depending on the thickness of the object that requires PWHT. Therefore, unnecessary long-time holding PWHT may cause an undesirable reduction in creep rupture strength, although it is needed to hold the PWHT time depending on the thickness of the object required in the relevant regulations or codes. The specimen with a PWHT holding time of more than $57.6 \mathrm{ks}$ ruptured at weld metal. Further, the 1,033-K holding temperature is lower than the $\mathrm{Ac}_{1}$ transformation temperature of the weld metal, as it is estimated that the $\mathrm{Ac}_{1}$ transformation temperature of weld metal for modified $9 \mathrm{Cr}-1 \mathrm{Mo}$ is approximately $1,043 \mathrm{~K}$ according to the EPRI Technical Report [6]. Therefore, the cause of rupture in the weld metal was examined using hardness testing. Figure 16 shows the distribution of hardness in the welding area for each holding time condition. The hardness decreased overall with an increase in the PWHT holding time. The lowest value of hardness ruptured at the weld metal with $57.6 \mathrm{ks}$ of PWHT holding time is almost the same value as that of the FGHAZ. Therefore, as suggested in Figure 11, it is assumed that the rupture occurs in weld metal where the value of hardness in the weld metal is almost the same as FGHAZ.

\section{Conclusions}

In this research, we clarified the appropriate PWHT conditions that would maintain the toughness and creep rupture strength of modified $9 \mathrm{Cr}-1 \mathrm{Mo}$ weld metal. The conclusions are as follows:

(1) The appropriate PWHT temperature range to maintain the toughness and the creep fracture strength for modified $9 \mathrm{Cr}-1$ Mo weld metal was $1,008 \mathrm{~K} \leq T \leq$ $1,033 \mathrm{~K}$. It is noted that this temperature range was the result obtained when the loaded stress during the creep test was as high as $108 \mathrm{MPa}$.

(2) The reasons why creep rupture occurred in such a short time are suggested as follows: when the PWHT temperature exceeds $1,033 \mathrm{~K}$, creep deformation easily occurs and decreases the effect of solution hardening and precipitation hardening for the matrix phase through coarsening $\mathrm{M}_{23} \mathrm{C}_{6}$ and $\mathrm{VN}$. The primary austenitic grain boundary in which the impurity element tends to enrich cannot withstand large creep deformation; therefore, creep voids and cracks occur.

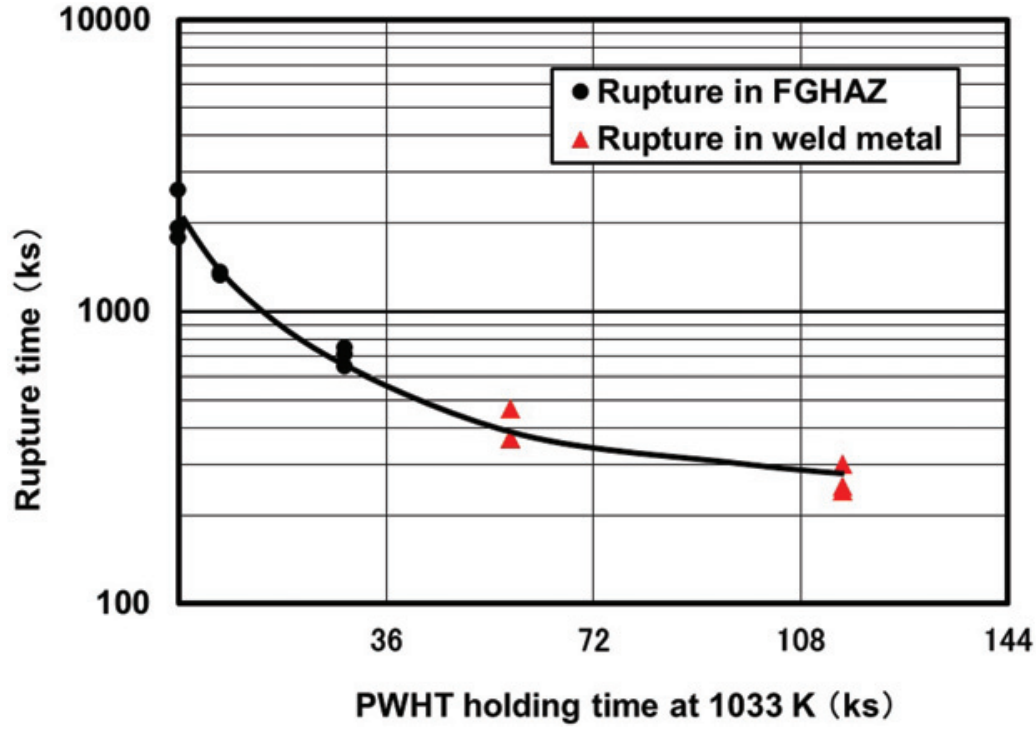

Figure 15: Effect of PWHT holding time at $1,033 \mathrm{~K}$ on creep rupture time of welded joints. 


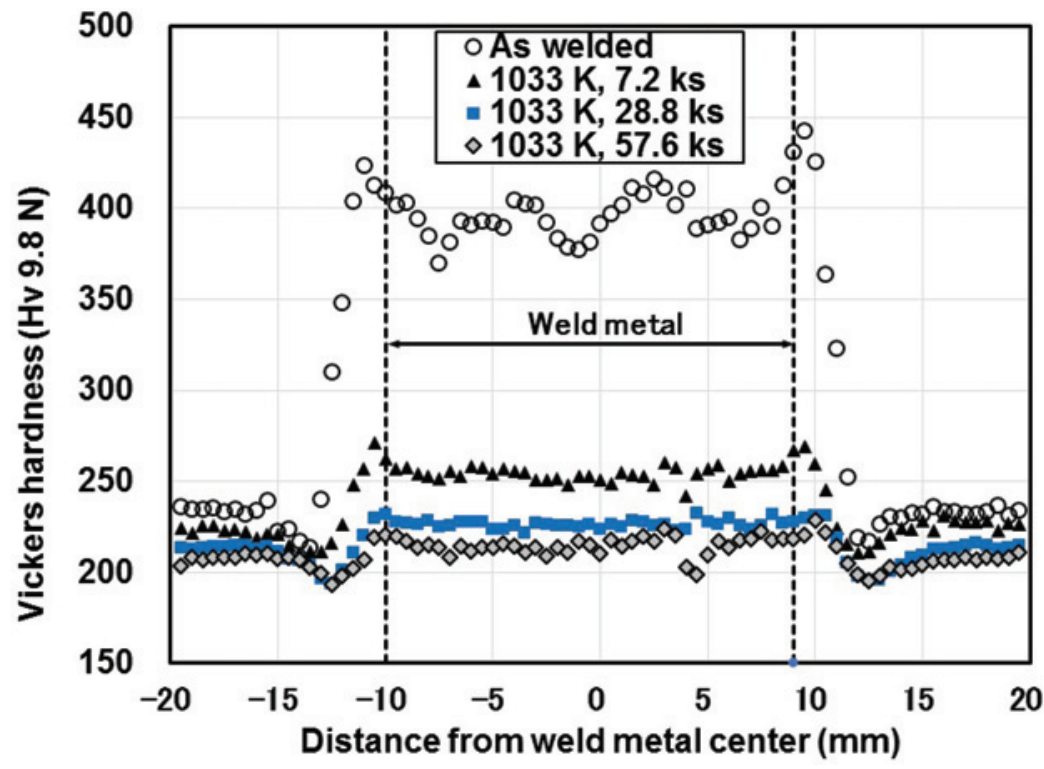

Figure 16: Comparison of Vickers hardness distributions at the welds in different PWHT holding time (before creep test).
(3) With a PWHT temperature of $1,033 \mathrm{~K}$, creep rupture strength decreases as the holding time of PWHT increases. Therefore, it is desirable to avoid longtime PWHT extending beyond the holding time specified in the relevant codes or regulations.

Acknowledgments: Part of this work was performed under the Joint Usage/Research Center on Joining and Welding, Osaka University.

\section{References}

[1] C.R. Brinkman, P.J. Maziasz, B.L.P. Keys and H.D. Upton, Oak Ridge National Laboratory Report, No.ORNL/9Cr/90-1, (1990).

[2] A. Iseta, Y. Sawaragi, and K. Yoshikawa, Tetsu-to-Hagane, 77 (1991) 582-589.
[3] Y. Tsuchida, K. Okamoto, and Y. Tokunaga, Q. J. Jpn. Weld. Soc., 13 (1995) 573-578.

[4] Y. Horii, S. Nishikawa, M. Sato, H. Murakawa, and J. Wang, Therm. Nucl. Power, 56 (2005) 43-52.

[5] C. Chovet, E. Galand, and B. Leduey, Weld. World, 52 (2008) 18-26.

[6] Guidelines and specifications for high-reliability Fossil power plants -best practice guideline for manufacturing and construction of grade 91 steel components-, EPRI (2011) Technical Report, B-5.

[7] S. Nishikawa, S. Ohkita, and Y. Horii, Q. J. Jpn. Weld. Soc., 26 (2008) 220-226.

[8] V. Gaffard, A.F. Gourgues-Lorenzon, and J. Besson, ISIJ Int., 45 (2005) 1915-1924.

[9] T. Sato, K. Tamura, K. Mitsuhara and R. Ikura, Long term creep rupture strength of $9 \mathrm{Cr} 1 \mathrm{MoNbV}$ narrow gap welded joints improved by normalizing and tempering after welding, Proceeding of CREEP8, Sun Antonio, Texas, (2007).

[10] C.R. Brinkman, D.J. Alexander and P.J. Maziasz, Modified 9Cr1Mo steel for advanced steam generator applications, ASME/ IEEE power generation conference, Boston, MA, (1990). 